\title{
Isolation of Chromanone and Isobenzofuran Derivatives from a Fungicolous Isolate of Epicoccum purpurascens
}

\author{
Nam Ho Lee, James B. Gloer, ${ }^{\star}$ and Donald T. Wicklow ${ }^{+}$ \\ Department of Chemstry, Cheju National Lniversity, Jeju 690-756, Korea. "E-mail: namhoracheju ac.kr \\ Department of Chemistry, Lnversity of low'a, low a City, low a 522+2, USA \\ ${ }^{2}$ Bioactive Agents Research Linit, Agricthtural Research Senice, National Center for.Agricultural Ctilization Research, \\ Lnited States Department of Agriculture, Peoria, Ilinois 61604, USA \\ Received Febriary 6, 2007
}

Key Words : Fungus. Epicoccum purptrascens, Natural product. Isolation

Mycoparasitic and fungicolous fungi are those which attack and colonize other fungal species. and often cause daniage to the host fungi. In many cases, at least part of this dantage appears to be caused by antifungal metabolites. In spite of such observations. these commonly occurring fungi remain relatively unexplored from a chemical standpoint. As a part of our ongoing studies of mycoparasitic and fungicolous fungi as sources of new antifungal metabolites. ${ }^{1-3}$ a fungicolous isolate of Epicoccum purparascens (MYC 1097 = NRRL 37031) was selected for investigation. Epicoccum purpurascens Elurenb. Ex Schlecht (syll. E. nignim Link) has been recorded as a colonist of decaying basidiocarps of larger fungi ${ }^{-1}$ and has been studied as an antagonist that produces antibiotics $^{* \$}$ and/or parasitizes the mycelium of fungal pathogens of crop plants. ${ }^{12}$ Studies of an organic extract from cultures of E. purpuraccens MYC 1097 afforded two new metabolites: 7-methoxy-4-oxo-chroman-5carboxylic acid methyl ester (1) and 1,3-dihydro-5-nethoxy7-methylisobenzofuran (2). The known compounds 4.5,6trihydroxy-7-methyl-3H-isobenzofuran-l-one (3) and 1,3dihydro-4.6-dihydroxy-7-methylisobenzofuran (4) were also obtained. Details of these studies are presented here.

The EtOAc extract of solid-substrate fermentation cultures of E. purpurascens was fractionated by Sephadex LH-20 column cluromatography. Chromanone metabolite 1 was obtained from the least polar fraction by subsequent silica gel column chromatography. HPLC separation of more polar fractions led to the isolation of the isobenzofuran derivatives $2-4$

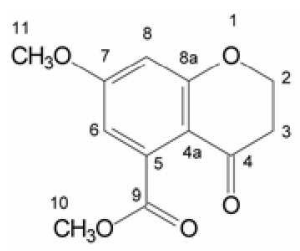

1

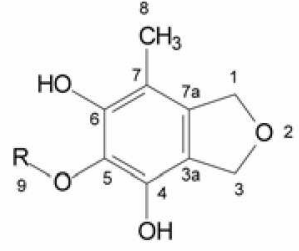

$\begin{array}{ll}2 \mathrm{R} & =\mathrm{CH}_{3} \\ 4 \mathrm{R} & =\mathrm{H}\end{array}$

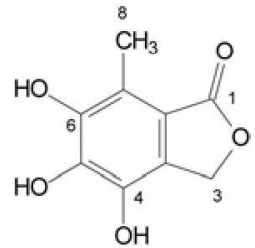

The molecular formula of compound 1 was determined to be $\mathrm{C}_{1} \mathrm{H}_{1} \mathrm{O}_{5}$ (seven unsaturations) on the basis of HREIMS analysis in combination with ${ }^{1} \mathrm{H}$ and ${ }^{13} \mathrm{C}$ NMR data. Com- pound 1 showed a simple ${ }^{1} \mathrm{H}$ NMR spectrum containing signals for two methoxy groups, an isolated $-\mathrm{OCH}_{2} \mathrm{CH}_{2}-$ unit, and two meta-coupled aromatic protons. The presence of two carbonyl carbons was indicated by ${ }^{12} \mathrm{C}$ NMR signals at $\delta_{c} 189.0$ and 169.7 . and by IR absorptions at $v_{\text {max }} 1733$ and $1685 \mathrm{~cm}^{-1}$. Analy sis of ${ }^{13} \mathrm{C}$ NMR $\delta$-values and HMQC data confirmed the presence of a 1,3-diosygenated. tetrasubstituted benzene ring. These results suggested that compound 1 has a disubstituted cluromanone structure. The locations of the substituents were established primarily on the basis of HMBC and NOE data (Figure 1). An HMBC correlation of $\mathrm{H}_{3}-\mathrm{ll}$ to $\mathrm{C}-7$ established the position of the aryl methosy group. while a correlation of $\mathrm{H}_{3}-10$ with carbosy carbonyl C -9 indicated the presence of a metlyyl ester unit. Correlations of the protons of the $-\mathrm{OCH}_{2} \mathrm{CH}_{2}$-unit with the carbonyl at $\delta .189 .0$ and two adjacent aryl carbons (C-4a and $\mathrm{C}-8 \mathrm{a}$ ) as shown in Figure 1 required formation of a pyranone ring fused to the benzenoid moiety. NOE correlations of $\mathrm{H}_{3}-$ 11 with both $\mathrm{H}-6$ and $\mathrm{H}-8$. and of $\mathrm{H}_{3}-10$ with $\mathrm{H}-6$, supported the regiochemistry shown in $\mathbf{1}$, and completed assignment of the structure. Chromanone derivatives have been isolated from a variety of fungi ${ }^{13}$ and plants. ${ }^{1 / 4}$ Among the known naturally occurring chromanones. nearly all have alkyl substituents at the C-2 or C-3 position. 5.7-Dihydroxy-8methosy-4-chromanone, previously isolated from a plant source, is appears to be the only prior example that is unsubstituted in the pyranone ring. To our knowledge. conpound 1 is the first fungal chromanone which bears no substituent at either the $\mathrm{C}-2$ or $\mathrm{C}-3$ position.

Known compound 4, originally reported as a potent antioxidant metabolite from Aspergilhus terrets, was isolated as a relatively major constituent of the extract, and identified

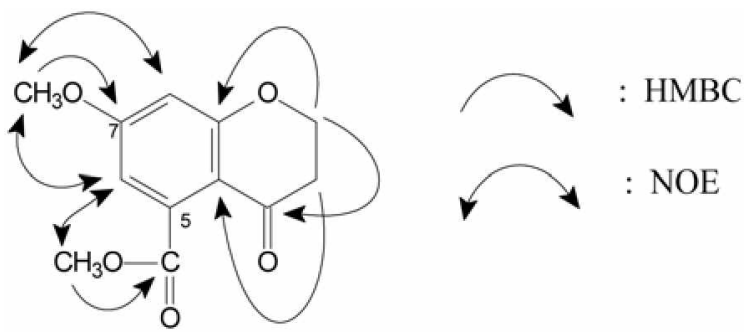

Figure 1. HMBC and NOE correlations for compound 1. 
by comparison of ${ }^{1} \mathrm{H}$ NMR. ${ }^{13} \mathrm{C}$ NMR. EIMS, and melting point data to literature values. ${ }^{16} \mathrm{Compound} 2$ showed ${ }^{1} \mathrm{H}$ and ${ }^{13} \mathrm{C}$ NMR data very sumilar to those of 4 . A $2.2-\mathrm{Hz}$ homobenzylic coupling constant between the two sets of methylene protons $\left(\mathrm{H}_{2}-1\right.$ and $\mathrm{H}_{2}-3$ was also observed, which is consistent with this type of dillydrobenzofuran structure. ${ }^{17}$ The only difference was the presence of an additional methoxy group $\left(\delta_{\mathrm{H}} 3.73: \delta, 61.0\right)$ in place of one of the phenolic $\mathrm{OH}$ groups. This was consistent with the molecular formula $\mathrm{C}_{10} \mathrm{H}_{1} \mathrm{O}_{4}$ which was established by HREIMS. The methoxy group was located at $\mathrm{C}-5$ on the basis of HMBC and ID NOE data. An HMBC correlation of $\mathrm{H}_{3}-9$ to the most upfield oxygen-substituted aromatic carbon $(\mathrm{C}-5)$, as well as NOE interactions between $\mathrm{H}_{3}-9$ and both phenolic $\mathrm{OH}$ signals, enabled placement of the methoxy group at $\mathrm{C}-5$. The location of the aryl methyl group at $\mathrm{C} .7$ was also supported by HMBC and NOE analysis. Compound 2 has not been previously reported. but the 4,5-dimethoxy analog has been described from another fungal source. ${ }^{18}$

The ${ }^{1} \mathrm{H}$ NMR spectrum of compound $3\left(\mathrm{C}_{8} \mathrm{H}_{5} \mathrm{O}_{5}\right.$ based on HREIMS) contained only two singlets at $\delta_{\mathrm{H}} 5.11$ and 2.41 . along with three broad $\mathrm{OH}$ peaks (using DMSO- $d_{6}$ as the NMR solvent). This observation, together with analysis of ${ }^{13} \mathrm{C}$ NMR data, suggested that 3 is an oxidized version of $t$ containing carboxy carbonyl group in place of one methylene unit with, to give an isobenzofuranone structure. The identity of this compound was confirmed as shown in $3 \mathrm{by}$ spectral analysis. This metabolite has been recently encountered as a metabolite of a marine isolate of Epicoccum sp., and was assigned the conmon name epicoccone. ${ }^{19}$ Other isobenzofuranones ${ }^{30 i}$ and isobenzofuran acetal ${ }^{\hat{1}}$ metabolites, which have structural similarities to $2-4$. have been previously isolated as metabolites from Aspergilhts spp.

Despite the source of the isolate and the prior reports of antibiotic activity for metabolites and extracts of $E$. purpurascens. standard disk assays for antifungal effects against Aspergilhus flonts NRRL 6541 and Futsarium verticillioides NRRL 25457 revealed that none of the four compounds isolated showed significant activity at levels up to $200 \mu \mathrm{g}$ /disk. Biosynthetically. conpounds $1-t$ are all presumed to be derived from the polyketide pathway. with 1 constructed from five acetate units. and $\mathbf{2 - 4}$ arising from four acetate units.

In conclusion. chemical studies of an organic extract of the fungicolous fungus Epicoccum purpurascens (MYC-1097 = NRRL 37031) led to isolation of two new metabolites 1,2 and two known compounds 3 and 4 . The structures of these compounds were elucidated on the basis of NMR and MS data.

\section{Experimental Section}

General experimental procedures. ${ }^{1} \mathrm{H}$ and ${ }^{13} \mathrm{C}$ NMR spectra were recorded with a Bruker DRX 400 instrument. HMBC and HMQC spectra were recorded at $600 \mathrm{MHz}\left({ }^{1} \mathrm{H}\right.$ dimension, Bruker AMX-600). NMR spectra were referenced to the solvent signals $\left(\mathrm{CDCl}_{3}\right.$ at $\delta_{\mathrm{H}} 7.24 / \delta_{\mathrm{C}} 77.0$ and acetone- $d_{6}$ at $\delta_{\mathrm{H}} 2.05 / \delta_{C}, 29.8$ ). UV measurements were performed with a Varian Cary 100 Bio UV-Vis spectrophotometer. IR measurements employed a FT-IR Perkin Elmer Spectrum BX instrument. Reversed-phase HPLC was perfonned using a $\mathrm{C}_{18}$-Alltech HS Hyperprep $100 \mathrm{BDS}$ column $(250 \times 10 \mathrm{~mm}, 8-\mu \mathrm{mm}$ particles $)$ using a Beckman $110 \mathrm{~B}$ solvent delivery module and a Beckman 168 diode array detector

Fungal material. A culture identified as Epicoccum purpurascens Elrenb. ex Schlecht was isolated by D.T.W. as MYC-1097 from an unidentified fungal growth on a dead hardwood branch collected from an area of Live OakPalmetto at Alligator Point near Panacea. Florida. by D.T.W. on April 30. 2000. A subculture of this isolate was deposited with the NRRL Collection at the USDA NCAUR and assigned the accession number NRRL 37031. General isolation and fermentation procedures used have been published elsewhere. ${ }^{17}$

Extraction and isolation. The culture was incubated on rice $(2 \times 50 \mathrm{~g})$ at $25^{\circ} \mathrm{C}$ for 30 days and extracted with EtOAc $(3 \times 500 \mathrm{~mL})$. The resulting EtOAc extract $(1.5 \mathrm{~g})$ was partitioned between $\mathrm{CH}_{3} \mathrm{CN}$ and hexane to obtain a $\mathrm{CH}_{3} \mathrm{CN}$-soluble mixture $(\mathrm{l} .1 \mathrm{~g})$ that was fractionated using a Sephadex LH-20 column ( $110 \mathrm{~g}$ ) eluting with $1: 1 \mathrm{CH}_{2} \mathrm{Cl}_{2-}$ acetone to provide 20 fractions. Non-polar fraction 2 (4.5 $\mathrm{mg}$ ) was further purified by passing through a small silica gel pad with 3:2 hexane-EtOAc to remove trace impurities to afford compound 1 (2.2 $\mathrm{mg}: R_{f} 0.24$ in 3.2 hexaneEtOAc). Reversed-phase HPLC separation of fraction 11 (12 mg) eluting with a $30-100 \% \mathrm{CH}_{3} \mathrm{CN}$ in $\mathrm{H}_{2} \mathrm{O}$ over $30 \mathrm{~mm}$ yielded compound $2(2.7 \mathrm{mg})$. Silica gel column chromatography of fraction $15(58 \mathrm{mg})$ using $10: 1 \mathrm{CHCl}_{3}-\mathrm{MeOH}$ provided compound + ( $37 \mathrm{mg} . R_{f} 0.34$ in $9: 1 \mathrm{CHCl}_{3}-\mathrm{MeOH}$ ). Silica gel column chromatograply of fraction $16(25 \mathrm{mg})$ using 9:1 $\mathrm{CHCl}_{3}-\mathrm{MeOH}$ provide a subfraction $(8.5 \mathrm{mg})$, which was further purified by reversed-phase HPLC eluting with a $30-100 \% \mathrm{CH}_{3} \mathrm{CN}$ in $\mathrm{H}_{2} \mathrm{O}$ over $30 \mathrm{~min}$ to yield compound 3 (4.3 mg: $t_{\mathrm{R}} 6.2 \mathrm{~min}$ ). Known compounds 3 and 4 were identified by analysis of MS and NMR data. and by comparison to literature values. ${ }^{17,18}$

7-Methoxy-4-ox0-chroman-5-carboxylic acid methyl ester (1): pale yellow solid: mp $94-96^{\circ} \mathrm{C}$; UV (MeOH) $\lambda_{\text {max }}$ 225 (e 11000): IR ( $\left.\mathrm{CHCl}_{3}\right) v_{\max } 2917,2846.1733,1685$, 1603. $1273,1146 \mathrm{~cm}^{-1}:{ }^{1} \mathrm{H}$ NMR $\left(\mathrm{CDCl}_{3,}, 400 \mathrm{MHz}\right) \delta 6.53$ (IH. d. $J=2.4$. H-6). 6.44 (IH. d. $J=2.4, \mathrm{H}-8$ ). $4.5 \mathrm{l}$ (2H. t. $\left.J=6.5, \mathrm{H}_{2}-2\right) .3 .92\left(3 \mathrm{H} . \mathrm{s}, \mathrm{H}_{3}-10\right), 3.82\left(3 \mathrm{H}, \mathrm{s} . \mathrm{H}_{3}-\mathrm{Il}\right), 2.74$ (2H. t. $\left.J=6.5 . \mathrm{H}_{z}-3\right):{ }^{13} \mathrm{C} \mathrm{NMR}\left(\mathrm{CDCl}_{2} .100 \mathrm{MHz}\right) \delta 189.0$ (C-4), 169.7 (C-9). 165.1 (C-7). 163.9 (C-8a), 136.2 (C-5). 112.2 (C-4a). 109.2 (C-6). 102.1 (C-8). 67.2 (C-2). 55.9 (C10). 52.9 (C-11). 37.4 (C-3): HMBC correlations ( $\mathrm{H} \rightarrow \mathrm{CH})$ $\mathrm{H}_{2}-2$ C-3. C-4. C-8a; $\mathrm{H}_{2}-3 \rightarrow \mathrm{C}-2$. C-4, C-4a; $\mathrm{H}-6 \rightarrow \mathrm{C}-4 \mathrm{a}$,

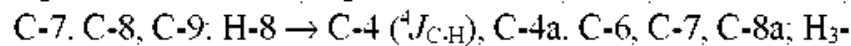
$10 \rightarrow \mathrm{C}-9: \mathrm{H}_{3}-1 \mathrm{l} \rightarrow \mathrm{C}-7$; EIMS $(70 \mathrm{eV}) m=236\left(\mathrm{M}^{+}\right.$; rel int 40). 208 (32), 205 (27), 178 (23). 165 (16), 150 (100): HREIMS $m \mathrm{z} 236.0688$ (calcd for $\mathrm{C}_{12} \mathrm{H}_{12} \mathrm{O}_{5}, 236.0685$ ).

1,3-Dihydro-4,6-dihydroxy-5-methoxy-7-methylisobenzofuran (2): light brown powder: $m p \quad 164-166{ }^{\circ} \mathrm{C}$; UV 
$(\mathrm{MeOH}) \lambda_{\max } 225\left(\varepsilon\right.$ 12000). $271(\varepsilon 2700): \mathrm{IR}\left(\mathrm{CHCl}_{3}\right) v_{\text {max }}$ 3348. 2858, 1376. 1116. $1055 \mathrm{~cm}^{-1}$. ${ }^{1} \mathrm{H}$ NMR (acetone-ds. $400 \mathrm{MHz}) \delta 7.81$ (s. C4-OH). 7.54 (s. C6-OH), 4.95 (t, $J=$ 2.2. $\left.\mathrm{H}_{2}-3\right), 4.91\left(\mathrm{t}, J=2.2, \mathrm{H}_{2}-1\right) .3 .74\left(\mathrm{~s}, \mathrm{H}_{3}-9\right) .2 .00\left(\mathrm{~s}, \mathrm{H}_{3}-\right.$ 8): ${ }^{13} \mathrm{C} \mathrm{NMR}\left(10: 1 \mathrm{CDCl}_{3}-\mathrm{CD}_{3} \mathrm{OD}, 100 \mathrm{MHz}\right) \delta \mathrm{l}+6.7(\mathrm{C}$. 6), $140.8(\mathrm{C}-4) .134 .6(\mathrm{C}-5), 134.1(\mathrm{C}-7 \mathrm{a}) .116 .1$ (C-3a). 109.2 (C-7), 73.5 (C-1). 72.1 (C-3). $61.0(\mathrm{C}-9), 11.7$ (C-8): HMBC correlations (acetone- $d s . \mathrm{H} \rightarrow \mathrm{C} \#) \mathrm{H}_{2}=1 \mathrm{C}-3 \mathrm{a} . \mathrm{C}-4$ $\left({ }^{4} J_{\mathrm{C}-\mathrm{H}}\right), \mathrm{C}-6\left({ }^{4} J_{\mathrm{C}-\mathrm{H}}\right)$, C -7, C $-7 \mathrm{a}: \mathrm{H}_{2}-3 \rightarrow \mathrm{C}-3 \mathrm{a}, \mathrm{C}-4, \mathrm{C}-7$ $\left({ }^{4} J_{\mathrm{C}-\mathrm{H}}\right) . \mathrm{C}-7 \mathrm{a} ; \mathrm{H}_{3}-8 \rightarrow \mathrm{C}-6 . \mathrm{C}-7 . \mathrm{C}-7 \mathrm{a} ; \mathrm{H}_{3}-9 \rightarrow \mathrm{C}-5 ; \mathrm{C} 4-\mathrm{OH}$ $\rightarrow$ C-3a. C.4. C-5: C6-OH $\rightarrow$ C-5. C.6. C.7: NOE correlations (acetone- $\left.d_{6}, \mathrm{H} \leftrightarrow \mathrm{H}\right) \mathrm{H}=-1 \leftrightarrow \mathrm{H}_{3}-8 ; \mathrm{H}_{3}-8 \leftrightarrow \mathrm{C} 6-\mathrm{OH}$ : $\mathrm{H}_{3}-9 \leftrightarrow \mathrm{C} 4-\mathrm{OH} ; \mathrm{H}_{3}-9 \leftrightarrow \mathrm{C} 6-\mathrm{OH} ;$ EIMS $(70 \mathrm{eV}) m z 196\left(\mathrm{M}^{+}:\right.$ rel int 98). 195 (96). 180 (39), 167 (100), 152 (52); HREIMS $m: \mathrm{z} 196.0734$ (calcd for $\mathrm{C}_{10} \mathrm{H}_{12} \mathrm{O}_{4 .}$ 196.0736).

4,5,6-Trihydroxy-7-methyl-3H-isobenzofuran-1-one (3): brown solid; $\mathrm{mp}>250^{\circ} \mathrm{C}$ : UV $(\mathrm{MeOH}) \lambda_{\max } 222(\varepsilon 25000)$. 253 (E 16000); IR ( $\left.\mathrm{CHCl}_{3}\right) v_{\max } 3164,1725.1352,1284$. $1025 \mathrm{~cm}^{-1}$ : ${ }^{1} \mathrm{H}$ NMR (CD $\left.\mathrm{OD}, 300 \mathrm{MHz}\right) \delta 5.11(2 \mathrm{H}, \mathrm{s} . \mathrm{H} \cdot$ 3), 2.41 (3H. s, H-8); ${ }^{13} \mathrm{C}$ NMR (3:1 CDCl $3-\mathrm{CD}_{3} \mathrm{OD}, 100$ $\mathrm{MHz}) \delta 172.9$ (C-1). 144.2 (C-6). 138.7 (C-4). 136.1 (C-5). $126.5(\mathrm{C}-3 \mathrm{a}) .117 .2(\mathrm{C}-7), 113.5(\mathrm{C}-7 \mathrm{a}), 66.6(\mathrm{C}-3), 9.1(\mathrm{C}-$ 8): HMBC correlations $(\mathrm{H} \rightarrow \mathrm{C} \#) \mathrm{H}_{2}-3 \rightarrow \mathrm{C}-1\left({ }^{4} J_{\mathrm{C}-\mathrm{H}}\right), \mathrm{C}-3 \mathrm{a}$. $\mathrm{C}-4, \mathrm{C}-5\left({ }^{4} J_{\mathrm{C}-\mathrm{H}}\right), \mathrm{C}-7 \mathrm{a} ; \mathrm{H}_{3}-8 \rightarrow \mathrm{C}-\mathrm{I}\left({ }^{4} J_{\mathrm{C}-\mathrm{H}}\right), \mathrm{C}-3 \mathrm{a}\left({ }^{4} J_{\mathrm{C}-\mathrm{H}}\right), \mathrm{C}-5$. C-6, C-7. Cross peak intensities for correlation of $\mathrm{H}_{3}-8$ to $\mathrm{C}$ 1 and C-3a were weak: HREIMS $m: z$ 196.0373 (calcd for $\mathrm{C}_{9} \mathrm{H}_{8} \mathrm{O}_{5}$ 196.0372); EIMS (70 eV) $m z 196\left(\mathrm{M}^{+}\right.$; rel int 67). $167(100)$.

Acknowledgment. Financial support for this research was provided by grants from Jeju HiDI (to N.H.L.) and the U.S. National Science Foundation (\# CHE-0315591. to J.B.G).

\section{References}

1. Deyrup. S. T.: Swenson. D. C.: Gloer. T. B.: Wicklow. D. T. J. Nat. Prod. 2006. 69.608.

2. Shim. S. H: Swenson. D. C.; Gloer, J. B.: Dowd. P. F.: Wicklow. D. T. Org. Lett $2006,8,1225$.

3. Mudur, S. V.: Gloer. J. B.: Wicklow. D. T. J. Antibiot. 2006. 59. 500 .

4. Hawksworth. D. L. In Biology of Conidial Fingi: Cole. G. T.: Kendrick. B.. Eds.: Academic Press: New York. 1981: pp 171244.

5. Burge, W. R.; Bucklev, L. J.: Sullivan. Jr.. J. D.; McGrattan. C. J.; Ikawa. M. J. Agric. Food Chem. 1976. 2t, 555.

6. Baute. M. A.: Deffieus. G.: Baute. R.: Neveu. A. J. Amibiot 1978. 31. 1099.

7. Brown. A. E.: Finlay. R.: Ward. T. S. Soil Biol. Biochent. 1987. 19. 657.

8. Madrigal, C.: Tadeo, J. L.; Melgarejo, P. H fycol. Res. 1991, 95. 1375

9. Chand. T.; Logan. C. Trans. Br. 1fycol Soc. 1984. 83. 107.

10. Piechenstain. F. L.: Bazzalo. M. E.: Roberts. A. M. I.: Ugalde. R. A. Mreol Res. 2001. 105.77.

11. Wu. W. S. Bot. Bull. Acad Sin. 1977. 18.25.

12. Zhou. T: Reeleder, R. D.: Sparace, S. A. Can. J. Bot. 1991, 69. 2503 .

13. MoGahren, W. J.: Ellestad, G. A.: Morton. G. O.: Kunstmann. M. P. J. Okg. Chem. 1972.37. 1636

14. Jong. T.-T.: Choul-Hwang. T.-Y. Phwochentistry 1997. H. 553.

15. Heller. W: Tamm. C. Helv Chim. Acta 1978. 61. 1257.

16. Ishikawa. Y.: Ito. T.: Lee. K. H. J. Jpn. Oil Chem. Soc. 1996. 45. 1321 .

17. Höler. U. Gloer, J. B.; Wictlow, D. T. I. Nat. Prod 2002, 65.876

18. Kobayashi, A.: Koguchi. Y: Takahashi, S.; Kanzaki. H.; Kawazu. K. Biosi Biotechol Biochem. 1993. 57. 1034.

19. Abdel-Lateff. A.: Fisch. K. M.: Wright. A. D.: König. G. M. Plantaled 2003.69.831.

20. Grove. J. F. J. Chem. Soc. Perhin Trans. I 1972. 2406

21. Nishihara, Y.: Takase, S.; Tsuji. E.; Hatanaka, H.; Hashimoto. S. J. Antibiot. 2001, 54. 297. 